\title{
Protective Effects of Baccharis dracunculifolia Leaves Extract against Carbon Tetrachloride- and Acetaminophen-Induced Hepatotoxicity in Experimental Animals
}

Túlio P. Rezende ${ }^{1}$, José Otávio do A. Corrêa ${ }^{2}$, Beatriz J. V. Aarestrup ${ }^{3}$, Fernando M. Aarestrup ${ }^{3}$, Orlando V. de Sousa ${ }^{4}$ and Ademar A. da Silva Filho ${ }^{1, *}$

1 Núcleo de Identificação e Pesquisa em Princípios Ativos Naturais - NIPPAN, Faculdade de Farmácia, Universidade Federal de Juiz de Fora, Rua José Lourenço Kelmer, s/n - Campus Universitário, Bairro São Pedro, CEP36036-900, Juiz de Fora, MG, Brazil

2 Laboratório de Bioatividade Celular e Molecular, Universidade Federal de Juiz de Fora, Rua José Lourenço Kelmer, s/n - Campus Universitário, Bairro São Pedro, CEP36036-900, Juiz de Fora, MG, Brazil

3 Laboratório de Imunopatologia e Patologia Experimental, Universidade Federal de Juiz de Fora, Rua José Lourenço Kelmer, s/n - Campus Universitário, Bairro São Pedro, CEP36036-900, Juiz de Fora, MG, Brazil

4 Laboratório de Farmacologia de Produtos Naturais, Universidade Federal de Juiz de Fora, Rua José Lourenço Kelmer, s/n - Campus Universitário, Bairro São Pedro, CEP36036-900, Juiz de Fora, MG, Brazil

* Author to whom correspondence should be addressed; E-Mail: ademar.alves@ufjf.edu.br; Tel.: +55-32-2102-3893; Fax: +55-32-2102-3801.

Received: 14 May 2014; in revised form: 25 June 2014 / Accepted: 26 June 2014 / Published: 2 July 2014

\begin{abstract}
In this work we investigated the in vivo protective effects of Baccharis dracunculifolia leaves extract (BdE) against carbon tetrachloride $\left(\mathrm{CCl}_{4}\right)^{-}$and acetaminophen (APAP)-induced hepatotoxicity. Total phenolic content, total flavonoid content, antioxidant DPPH radical scavenging activity, and HPLC analysis were performed. Our results showed that pretreatment with BdE significantly reduced the damage caused by $\mathrm{CCl}_{4}$ and APAP on the serum markers of hepatic injury, AST, ALT, and ALP. Results were confirmed by histopathological analysis. Phytochemical analysis, performed by HPLC, showed that BdE was rich in $p$-coumaric acid derivatives, caffeoylquinic acids and flavonoids. BdE also showed DPPH antioxidant activity $\left(\mathrm{EC}_{50}\right.$ of $15.75 \pm 0.43 \mu \mathrm{g} / \mathrm{mL})$, and high total phenolic $(142.90 \pm 0.77 \mathrm{mg} \mathrm{GAE} / \mathrm{g})$ and flavonoid
\end{abstract}


$(51.47 \pm 0.60 \mathrm{mg} \mathrm{RE} / \mathrm{g})$ contents. This study indicated that $B$. dracunculifolia leaves extract has relevant in vivo hepatoprotective properties.

Keywords: Baccharis dracunculifolia; Brazilian green propolis; acetaminophen; carbon tetrachloride; hepatoprotective

\section{Introduction}

Reactive oxygen species (ROS) are generated spontaneously in cells during metabolism and are implicated in the aetiology of different degenerative diseases, such as heart diseases, stroke, rheumatoid arthritis, diabetes and cancer [1]. Oxidative stress is also the main cause of liver diseases, and plant extracts with antioxidant activity have received special attention as possible preventive and therapeutic agents, since they are able to decrease the production and/or to eliminate produced ROS [2,3]. Chemicals, such as carbon tetrachloride $\left(\mathrm{CCl}_{4}\right)$ and acetaminophen (APAP) produce liver toxicity associated to oxidative stress, causing necrosis of hepatocytes and, as a result, releasing enzymes, such as aspartate aminotransferase (AST), alanine aminotransferase (ALT), and alkaline phosphatase (ALP) into the circulating blood [4].

Previous studies have shown that the use of some natural compounds found in teas, fruits, and vegetables is associated with low risk of several degenerative diseases [1]. In addition, natural antioxidant substances may act against both $\mathrm{CCl}_{4}$ and APAP-toxicity, decreasing production and/or eliminating the free radicals responsible for hepatic damage [5]. Consequently, there is a great deal of interest in plants, beverages and foods that contain antioxidants and health-promoting phytochemicals as potential therapeutic agents [1].

One such plant is Baccharis dracunculifolia D.C. (Asteraceae), popularly known as "alecrim do campo" and "vassoura", which is used as a tea with anti-inflammatory properties in Brazilian folk medicine [6] and as a hepatoprotective [7]. The aerial parts of B. dracunculifolia have also been used in farms to clean mud ovens before making cookies, which thus acquire the aroma of this plant [6]. In this way, the essential oil of $B$. dracunculifolia has commercial value due to its strong lasting exotic aroma, and its potentially wide range of applications, such as an additive in cosmetics, foods and agrochemicals [8].

Besides its use in traditional medicine, B. dracunculifolia is the most important botanical source of Southeastern Brazilian propolis, which due to its colour is called as green propolis [9]. Propolis is a natural resinous substance collected by honeybees (Apis mellifera) from buds and exudates of plants to be used as a protective barrier in the beehive that displays many biological activities, such as antioxidant [10], antibacterial [11] and hepatoprotective activity against both $\mathrm{CCl}_{4}$ [12] and APAP-induced damage [13].

Currently, because of their biological activities, Brazilian green propolis and B. dracunculifolia leaves are used in foods and beverages, especially in Brazil and Japan, aiming to improve health and to prevent several diseases, such as inflammation and cancer [14]. Recently, it was verified that a glycolic extract of B. dracunculifolia leaves exhibited in vitro antioxidant activity [2], which supposes that it may have some health beneficial effects in vivo. However, the extent of its protective effects in vivo 
depends on the bioavailability of its active compounds for intestinal absorption, metabolism, and subsequent interaction with target tissues. In this line, in the present study, we investigated the activity of $B$. dracunculifolia leaves extract against $\mathrm{CCl}_{4}$ - and APAP-induced liver damage, which have not been reported.

\section{Results and Discussion}

\subsection{HPLC Analysis of Hydroalcoholic Extract of B. dracunculifolia (BdE)}

The HPLC analysis of BdE allowed the identification of caffeic acid (1), $p$-coumaric acid (2), 3,4-di- $O$ caffeoylquinic acid (3), 3,5-di-O-caffeoylquinic acid (4), 4,5-di- $O$-caffeoylquinic acid (5), cinnamic acid (6), aromadendrin-4'-O-methyl ether (7), drupanin (8), artepillin C (9), and baccharin (10) as the major identified compounds (Figure 1A, B).

\subsection{DPPH Free Radical Scavenging Assay, Total Phenolic Content and Total Flavonoid Content}

DPPH radical scavenging activities of $\mathrm{BdE}$ (which ranged from 5 to $50 \mu \mathrm{g} / \mathrm{mL}$ ) increased in a concentration-dependent manner (18.13\% to $93.28 \%$ of inhibition) with an $\mathrm{EC}_{50}$ of $15.75 \pm 0.43 \mu \mathrm{g} / \mathrm{mL}$, while rutin showed an $\mathrm{EC}_{50}$ of $8.71 \pm 0.24 \mu \mathrm{g} / \mathrm{mL}$. Total phenolic content of $\mathrm{BdE}$ was $142.90 \pm 0.77 \mathrm{mg} \mathrm{GAE} / \mathrm{g}$ of BdE. Total flavonoid content obtained from BdE was $51.47 \pm 0.60 \mathrm{mg}$ of rutin equivalent $(\mathrm{RE}) / \mathrm{g}$ of $\mathrm{BdE}$.

Figure 1. (A) Representative HPLC chemical profile of BdE recorded at $275 \mathrm{~nm}$. (B) Chemical structures of major compounds identified from BdE: caffeic acid (1), $p$-coumaric acid (2), 3,4-di- $O$-caffeoylquinic acid (3), 3,5-di- $O$-caffeoylquinic acid (4), 4,5-di- $O$ caffeoylquinic acid (5), cinnamic acid (6), aromadendrin-4'- $O$-methyl ether (7), drupanin (8), artepillin C (9), and baccharin (10).

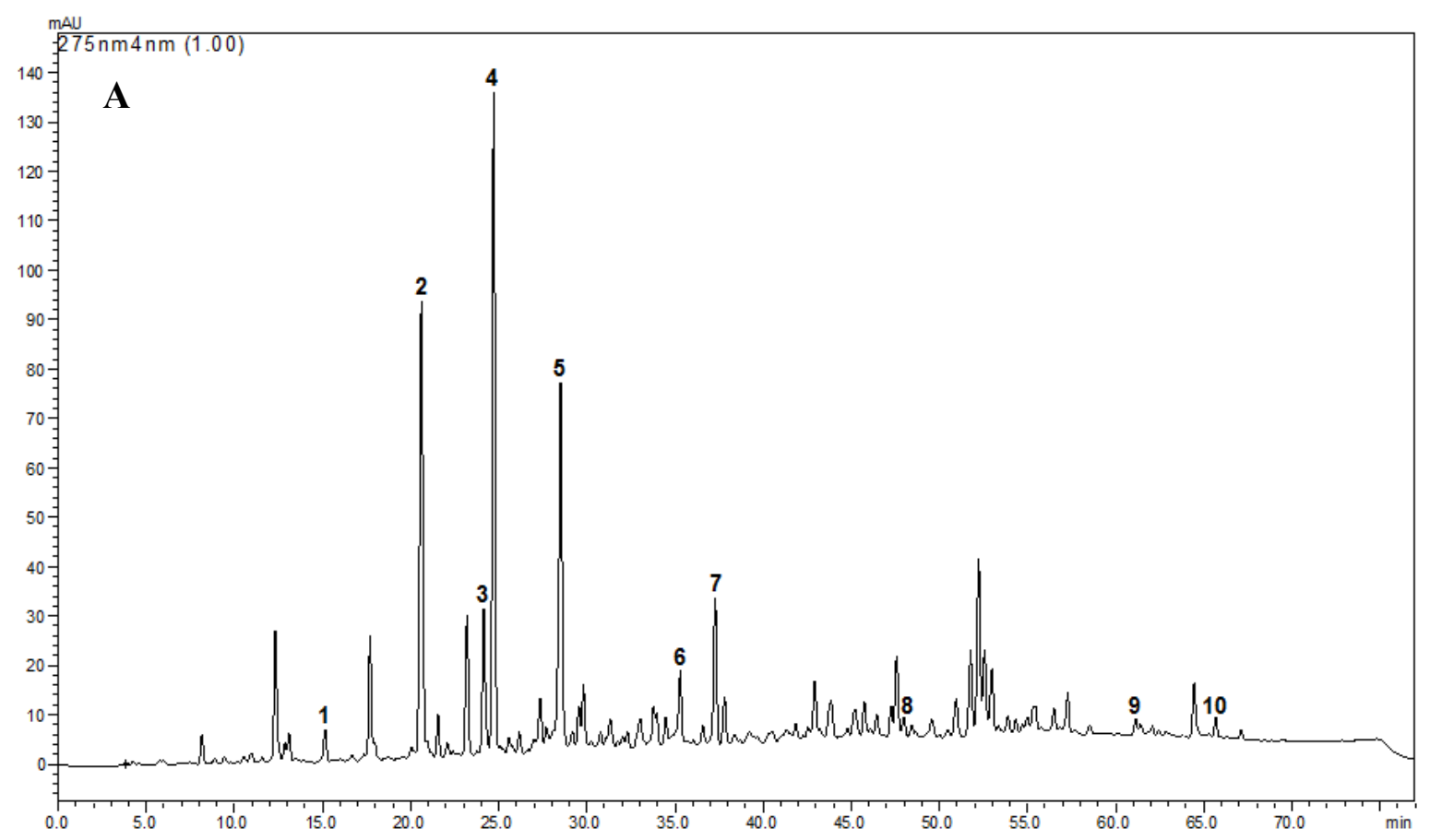


Figure 1. Cont.

B<smiles>[R]c1ccc(/C=C/C(=O)O)cc1[R]</smiles>

Caffeic acid $\left(\mathrm{R}_{1}=\mathrm{OH}\right.$ and $\left.\mathrm{R}_{2}=\mathrm{OH}\right)(\mathbf{1})$ $p$-Coumaric acid $\left(\mathrm{R}_{1}=\mathrm{H}\right.$ and $\left.\mathrm{R}_{2}=\mathrm{OH}\right)(2)$ Cinnamic acid $\left(R_{1}=R_{2}=H\right)(6)$<smiles>[2H]C1CC(O)(C(=O)O)CC([2H])C1[2H]</smiles>

3,4-di- $O$-Caffeoylquinic acid $\left(\mathrm{R}_{1}=\mathrm{R}_{2}=\right.$ caffeoyl and $\left.\mathrm{R}_{3}=\mathrm{OH}\right)(3)$ 3,5-di-O-Caffeoylquinic acid $\left(\mathrm{R}_{1}=\mathrm{R}_{3}=\right.$ caffeoyl and $\left.\mathrm{R}_{2}=\mathrm{OH}\right)$ (4) 4,5-di-O-Caffeoylquinic acid $\left(\mathrm{R}_{1}=\mathrm{OH}\right.$ and $\mathrm{R}_{2}=\mathrm{R}_{3}=$ caffeoyl) (5)<smiles>COc1ccc([C@H]2Oc3cc(O)cc(O)c3C(=O)C2O)cc1</smiles>

Aromadendrin-4'-O-methyl ether (7)<smiles>[R6]c1cc(/C=C/C(=O)O)cc([R6])c1O</smiles>

Drupanin $\left(\mathrm{R}_{1}=\mathrm{H}\right.$ and $\mathrm{R}_{2}=$ prenyl) (8) Artepillin $\mathrm{C}\left(\mathrm{R}_{1}=\right.$ prenyl and $\mathrm{R}_{2}=$ prenyl $)(\mathbf{9})$

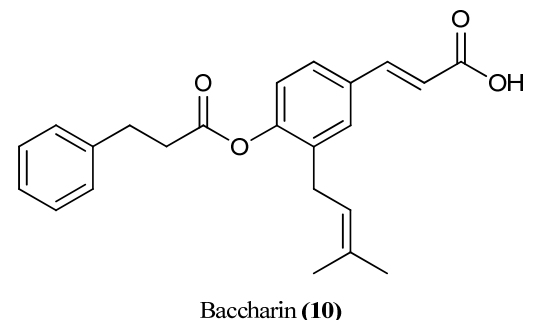

\section{3. $\mathrm{CCl}_{4}$-Induced Hepatotoxicity}

The effects of BdE at four dose levels $(10,25,50$ and $100 \mathrm{mg} / \mathrm{kg}$ bw, p.o.) on serum marker enzymes in $\mathrm{CCl}_{4}$-induced hepatic injury are shown in Figure 2.

Hepatic injury induced by $\mathrm{CCl}_{4}$ caused significant $(p<0.001)$ rise in marker enzymes ALT, AST, and ALP when compared with the normal control group. On the other hand, administration of BdE $(100 \mathrm{mg} / \mathrm{kg}$ bw, p.o.) significantly $(p<0.001)$ attenuated the increased levels of the serum enzymes produced by $\mathrm{CCl}_{4}$, and caused a subsequent recovery towards normalization like that of silymarin (100 mg/kg bw, p.o.) treatment. The activity of $\mathrm{BdE}(100 \mathrm{mg} / \mathrm{kg} \mathrm{bw}$, p.o.) is comparable to the silymarin, a known hepatoprotective drug.

Figure 2. Effect of BdE on mice intoxicated with carbon tetrachloride $\left(\mathrm{CCl}_{4}\right)$. Levels of liver enzymes AST (a), ALT (b) and ALP (c).

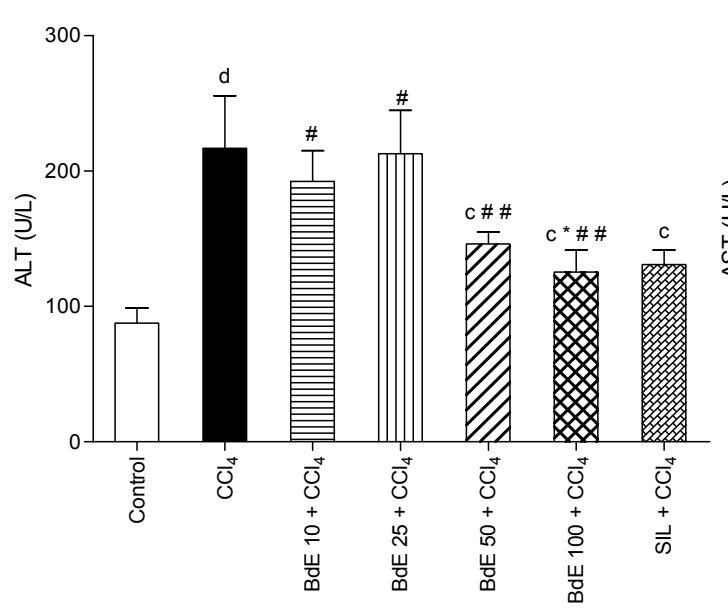

(a)

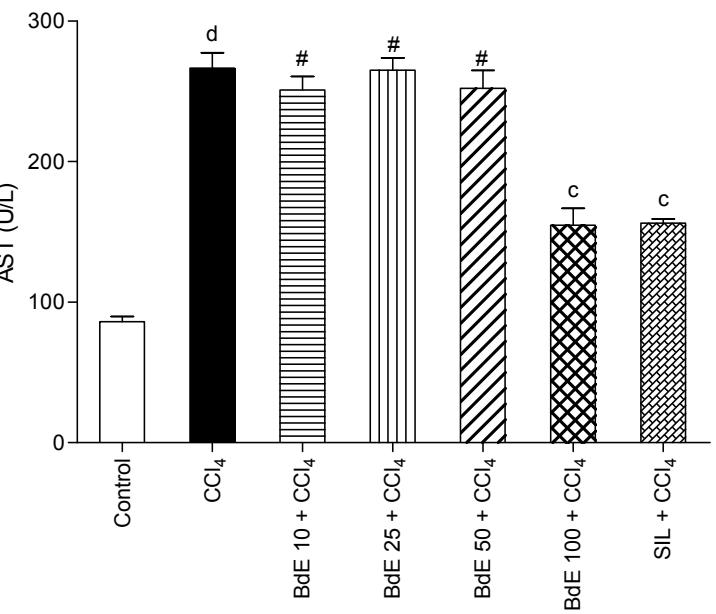

(b) 
Figure 2. Cont.

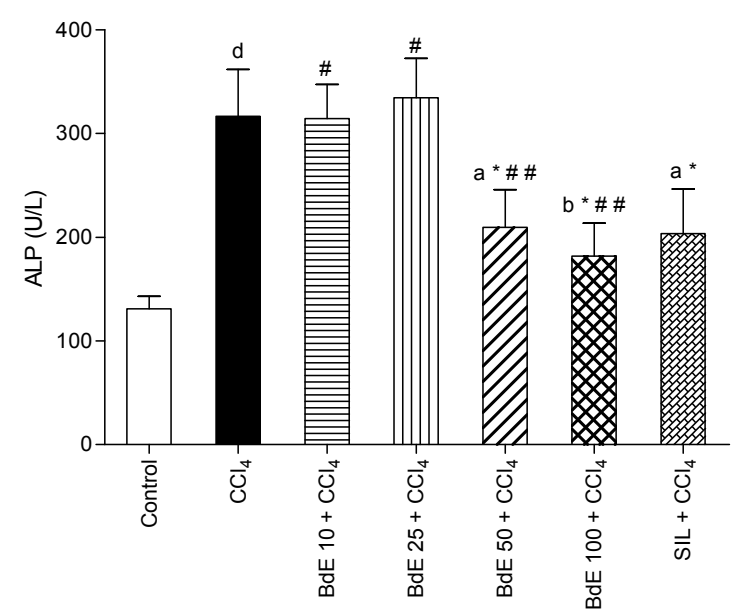

(c)

Data are expressed as the mean \pm S.D. for six animals per group. ${ }^{\text {a }} p<0.05$; ${ }^{\mathrm{b}} p<0.01 ;{ }^{\mathrm{c}} p<0.001$ (vs. $\mathrm{CCl}_{4}$ group); ${ }^{\mathrm{d}} p<0.001$ (vs. Control group); N.S. ${ }^{*} p>0.05$ (vs. Control group). Notes: \#,\# Non-significant differences between BdE groups.

\subsection{APAP-Induced Hepatotoxicity}

Administration of APAP (600 mg/kg bw, p.o.) caused significant ( $p<0.001)$ liver injury, as demonstrated by the increase of serum marker enzymes of ALT by $87.36 \%$, AST by $106.88 \%$, and ALP by $37.86 \%$ compared to control group (Figure 3 ).

Administration of BdE (50 and $100 \mathrm{mg} / \mathrm{kg}$ bw, p.o.) significantly attenuated the increased levels of the serum enzymes produced by APAP, like the silymarin (100 $\mathrm{mg} / \mathrm{kg}$ bw, p.o.) treatment. Non-significant differences were observed between groups treated with 50 and $100 \mathrm{mg} / \mathrm{kg}$ of BdE.

Figure 3. Effect of BdE on rats intoxicated with acetaminophen (APAP). Levels of liver enzymes AST (a), ALT (b), ALP (c).

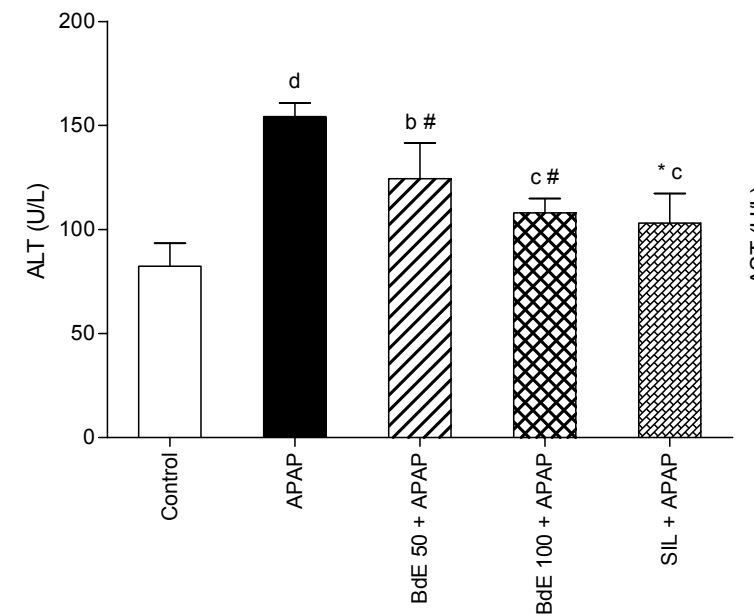

(a)

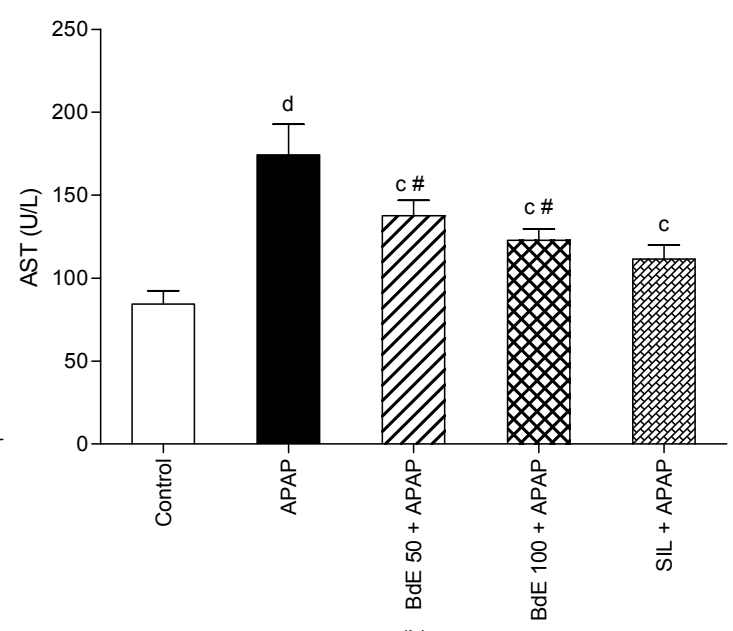

(b) 
Figure 3. Cont.

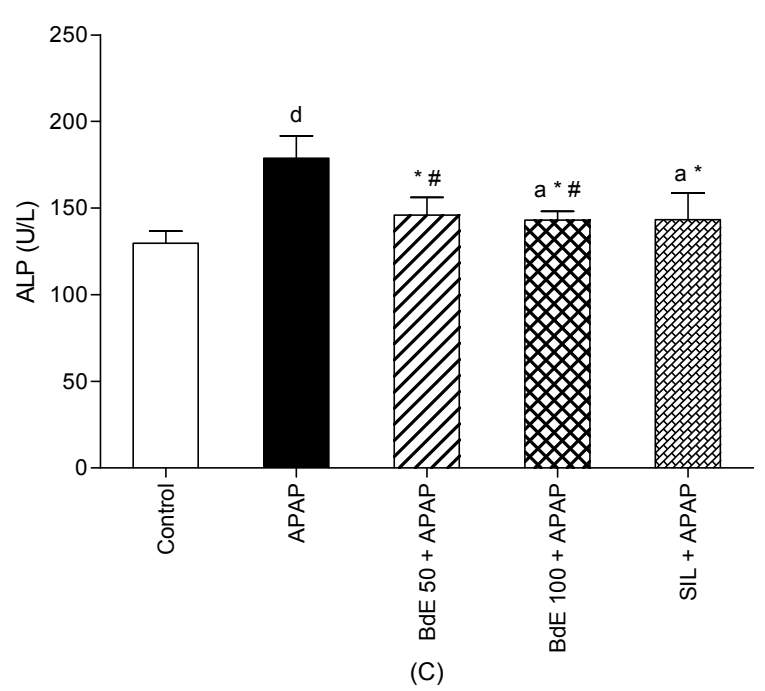

Data are expressed as the mean \pm S.D. for six animals per group. ${ }^{\mathrm{a}} p<0.05 ;{ }^{\mathrm{b}} p<0.01 ;{ }^{\mathrm{c}} p<0.001$ (versus $\mathrm{CCl}_{4}$ group); ${ }^{\mathrm{d}} p<0.001$ (versus Control group); N.S. ${ }^{*} p>0.05$ (versus Control group). Notes: ${ }^{\#}$ Non-significant differences between BdE groups.

\subsection{Histopathological Studies}

Histopathological analysis of liver sections from groups treated with silymarin $(100 \mathrm{mg} / \mathrm{kg} \mathrm{bw})$ (Figure $4 \mathrm{a}$ ), BdE (100 mg/kg bw) (Figure 4b), and normal control (vehicle) group (Figure 4c) exhibited characteristics consistent with normality, in which the capillary network can be seen between Remak's fibres. Hepatocytes of zones 1,2 and 3 (taking as reference the portal triad and central venule) displayed intensely eosinophilic cytoplasm, typical glycogen granules and intracytoplasmic basophilic round nuclei and were strongly basophilic. Occasionally, in the group treated with BdE $(100 \mathrm{mg} / \mathrm{kg} \mathrm{bw})$, cells were observed in zone 3 and 2 with bulkier cores and dispersed chromatin as well as discreet hyaline accumulation. In all regions, including such areas, normality was noted in capillary pattern and maintenance of trabecular bone (Figure 4b). Liver sections from the group treated with BdE (10 mg/kg bw) showed intensely eosinophilic areas with loss of trabecular cytoarchitecture typical around the zone 3 of the hepatic lobes, corresponding to coagulation necrosis, occasionally expanding to the same region in adjacent lobes (Figure 4d). Additionally, in zone 2, surrounding the necrotic area, isolated hepatocytes under apoptosis and necrosis were observed and zone 1 showed characteristics compatible with normality (Figure $4 \mathrm{~d})$. The group treated with BdE $(25 \mathrm{mg} / \mathrm{kg} \mathrm{bw})$ displayed confluent necrosis in zone 3 and part of zone 2 in the most lobes observed, with occasional continuing this process to centroacinares regions of neighboring lobes (Figure 4c). Also, some hepatocytes in zone 1 exhibited consistent changes with degenerative accumulations, without loss of radial architectural arrangement, capillary changes and acinar cell organization (Figure 4c). Samples from the group treated with $\mathrm{BdE}(50 \mathrm{mg} / \mathrm{kg} \mathrm{bw})$ displayed maintenance of trabecular radial cytoarchitecture on all lobe areas (Figure 4f). In zone 3, isolated hepatocytes with bulkier core and dispersed chromatin were observed. Furthermore, in zone 1, hyaline accumulation was slightly more significant of that observed in the group treated with BdE $(100 \mathrm{mg} / \mathrm{kg} \mathrm{bw})$ (Figure $4 \mathrm{~b})$. Displayed glycogen storage was compatible with normality. Hepatotoxicity control $\left(\mathrm{CCl}_{4}\right.$ group) exhibited 
vascular congestion associated with damaged areas of radial trabecular structure and lobular structure loss (Figure 4g). Hepatocytes with degeneration features, necroinflammatory "spotty necrosis" and several phases of apoptosis were observed in zone 2, associated with dilatation of sinusoidal capillaries and Disse's space (Figure 4h). Beyond that, in none of the samples were areas of diffuse inflammatory infiltrate, polymorphonuclear or mononuclear, as well as fibrosis, observed. The BdE (100 mg/kg bw)-treated group showed normal liver architecture as it possessed higher hepatoprotective action (Figure 4b).

Figure 4. Protective effects of $\mathrm{BdE}$ pretreatment on $\mathrm{CCl}_{4}$-induced hepatotoxicity in rats. Photomicrographs of liver sections from animals treated with: (a) silymarin $(100 \mathrm{mg} / \mathrm{kg})$, (b) BdE (100 mg/kg), (c) vehicle, (d) BdE (10 mg/kg), (e) BdE (25 mg/kg), (f) BdE $(50 \mathrm{mg} / \mathrm{kg}),(\mathbf{g})$ and $(\mathbf{h}) \mathrm{CCl}_{4}(5.0 \mathrm{~mL} / \mathrm{kg})$ (hepatotoxicity control). Portal triad (arrowhead). Central venule (asterisk). Hepatic vein (arrow). Delimitations of zones 1, 2 and 3 (line). Staining H.E. Magnification 400×.
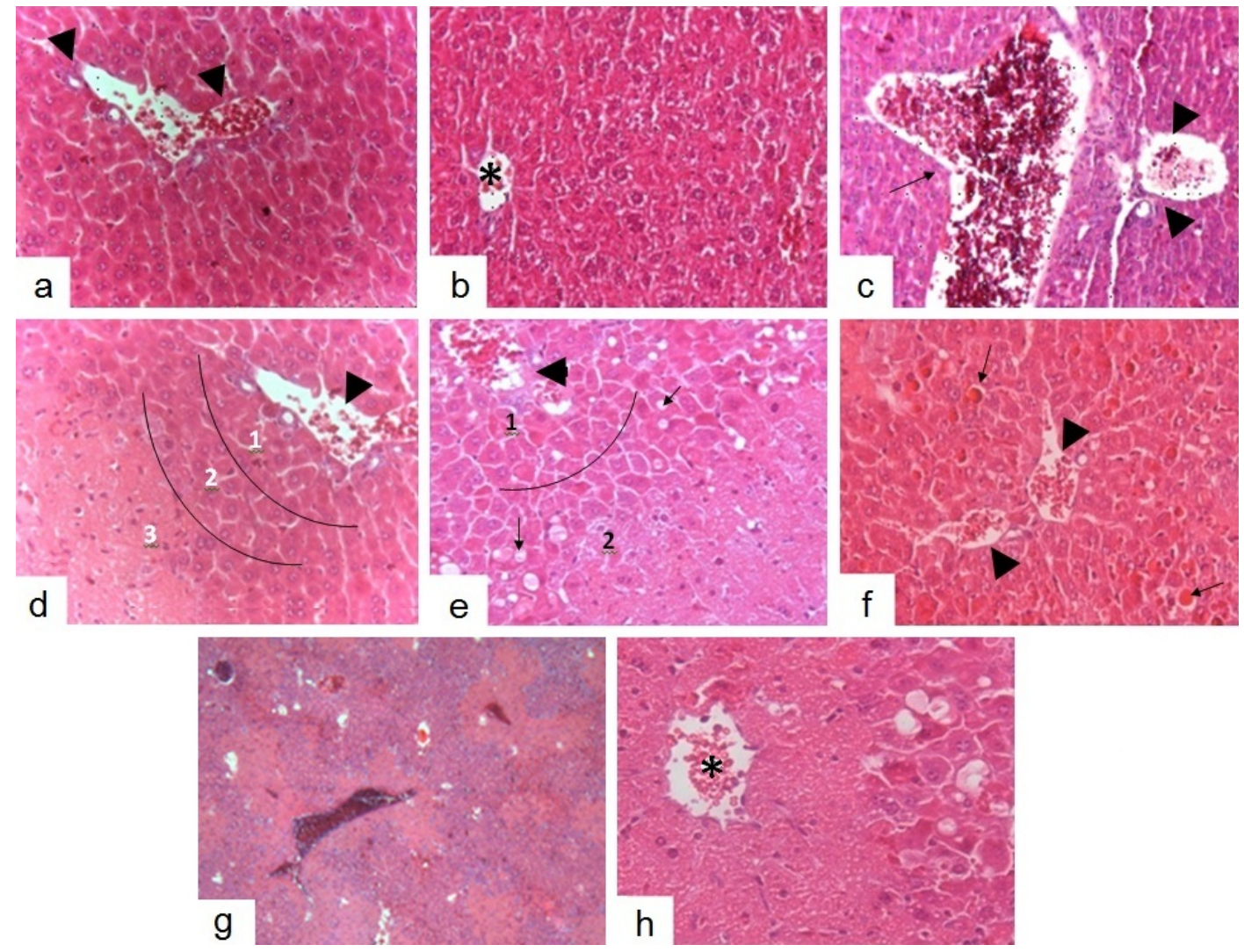

\subsection{Discussion}

B. dracunculifolia secondary metabolites are collected by bees (Apis mellifera) to produce Brazilian green propolis, which is of great importance for the food and pharmaceutical industries [10,11]. Besides, $B$. dracunculifolia is a medicinal plant used as an infusion to prevent diseases [6,7]. In the present study, the capability of $B$. dracunculifolia leaves extract (BdE) to protect against $\mathrm{CCl}_{4^{-}}$and APAP-induced hepatotoxicity was investigated.

Our results demonstrated that BdE possess antioxidant activity and high contents of phenolics and flavonoids. The DPPH free radical test is a decolorization assay, which measures the relative antioxidant abilities of compounds or extracts to scavenge the free radical (DPPH) generated, which makes this assay 
system one of the most commonly used antioxidant test methods [15]. Phenolic compounds are ubiquitous in plants and are characterized by hydroxylated aromatic rings and known to act as antioxidants [16]. Our results demonstrated that $\mathrm{BdE}$ possesses significant amounts of flavonoids and mainly phenolic compounds, which may be responsible for the antioxidant activity of BdE. Previous phytochemical studies of $B$. dracunculifolia reported the identification of phenolic acid derivatives and flavonoids as the major compounds of its aerial parts $[17,18]$. Recently, it was reported that a glycolic extract of $B$. dracunculifolia, rich in phenolics, also possesses in vitro antioxidant activity [2].

Considering the chemical composition of BdE, individual phenolic compounds were determined by HPLC analysis, which demonstrated that phenolic acids (caffeic acid, $p$-coumaric acid, cinnamic acid, drupanin, baccharin and artepillin $\mathrm{C}$ ), hydroxycinnamic acids (3,4-di- $O$-caffeoylquinic acid, 3,5-di- $O$ caffeoylquinic acid and 4,5-di- $O$-caffeoylquinic acid) and flavonoid compounds (aromadendrin-4'methyl ether) were predominant in the composition of BdE, which is in agreement with previous investigations [19]. Among the major compounds identified in BdE, caffeic acid (1) and its derivatives 3, 4 and 5 have shown potent antioxidant activity in the DPPH assay. It was also reported that p-coumaric acid (2) and its prenylated derivatives drupanin (8) and artepillin $\mathrm{C}$ (9) possess strong antioxidant activity [20]. These data allow us to suggest that the phenolic compounds present in BdE could be responsible for its antioxidant activity. Also, we hypothesize that the major metabolites of $\mathrm{BdE}$ might protect the liver from $\mathrm{CCl}_{4}$ and APAP-induced damages.

Then, in order to evaluate the hepatoprotective effect of $\mathrm{BdE}$, a $\mathrm{CCl}_{4}$-induced hepatotoxicity model was employed first. This experimental model has been used extensively to investigate hepatoprotective activity on different experimental animals [21]. The hepatotoxicity induced by $\mathrm{CCl}_{4}$ is mainly due to its metabolite $\mathrm{CCl}_{3}{ }^{-}$, a free radical that alkylates cellular proteins and other macromolecules with a simultaneous attack on polyunsaturated fatty acids. In the presence of oxygen, lipid peroxides are produced, leading to liver damage [21], characterized by fatty liver, cirrhosis and necrosis [22]. Oxidative stress is considered to play a prominent causative role in many diseases, including liver damage [4]. Oxidative stress is the state of imbalance between the level of antioxidant defense system and production of ROS, such as superoxide radical $\left(\mathrm{O}^{2-}\right)$, hydroxyl radical $\left(\mathrm{OH}^{-}\right)$and hydrogen peroxide $\left(\mathrm{H}_{2} \mathrm{O}_{2}\right)$. Thus, the antioxidant activity or the inhibition of the generation of free radicals is important for protection against $\mathrm{CCl}_{4}$-induced hepatotoxicity [21,22]. In addition, in $\mathrm{CCl}_{4}$-induced hepatotoxicity, the extent of hepatic damage is assessed by the increased level of cytoplasmatic enzymes (ALT, AST and ALP), which leads to leakage of large quantities of enzymes into the blood circulation and could be regarded as an index of the liver parenchymal cells damage [4]. Clinically, the general strategy for prevention and treatment of the $\mathrm{CCl}_{4}$-induced hepatotoxicity includes reducing the production of reactive metabolites [23]. Also, $\mathrm{CO}_{2}$-induced hyperventilation has been used for the treatment of intoxication with $\mathrm{CCl}_{4}$, since that liver metabolizes normally less than $1 \%$ of the ingested $\mathrm{CCl}_{4}$, and the remainder is excreted by the lungs [24,25].

The treatment with BdE was capable of significantly and dose-related attenuation of the increased levels of the serum enzymes (ALT, AST and ALP), produced by $\mathrm{CCl}_{4}$-induced hepatotoxicity, like silymarin, a known hepatoprotective drug [5]. The protective effects exerted by BdE against $\mathrm{CCl}_{4}$-induced hepatotoxicity were further confirmed by conventional histopatological assessment. It was observed that $\mathrm{CCl}_{4}$-intoxicated mice, pretreated with $\mathrm{BdE}$, showed normal liver architecture, demonstrating the hepatoprotective action of BdE. 
In an attempt to verify the protective effects of BdE against APAP-induced liver damage, only the most active doses of $\mathrm{BdE}$ found in the $\mathrm{CCl}_{4}$-induced hepatotoxicity model (50 and $100 \mathrm{mg} / \mathrm{kg} \mathrm{bw}$ ) were employed. Acetaminophen has been used extensively during the last 40 years as a model toxicant, and one of the most popular models to test potentially hepatoprotective agents, especially natural products [26]. APAP toxicity is initiated by the metabolism of a small fraction of the dose by cytochrome P450 enzymes, in order to form $N$-acetyl- $p$-benzoquinone imine (NAPQI). An increasing amount of NAPQI reacts with protein sulfhydryl groups, causing covalent adduction of cellular proteins. In addition, NAPQI binds to mitochondrial proteins, leading to an initial mitochondrial oxidative stress, which is an important early event in the mitochondrial dysfunction after APAP overdose. Also, ROS have been proved to associate with the intoxication by APAP, and the major ROS of APAP toxicity in mice is superoxide $\left(\mathrm{O}_{2}{ }^{-}\right)$[27]. In addition, AST, ALT, and ALP activities are well-documented biochemical markers of hepatic dysfunction after APAP-induced toxicity. Clinically, the antioxidant $N$-acetyl-L-cysteine (NAC) is known to restore the glutathione depleted by NAPQI during APAP metabolism, and therefore, NAC is used in the human clinical treatment of APAP-induced toxicity [23].

Thus, the administration of BdE significantly reduced the activities of AST, ALT and ALP compared to the APAP-induced toxicity group. Then, it is suggested that, in vivo, BdE may scavenge free radicals and protect mitochondrial, endoplasmatic reticulum, and plasma membranes from damage induced by free radicals. Several studies have indicated that natural compounds exhibited strong antioxidant activity that could act against $\mathrm{CCl}_{4}$ - and APAP-induced liver damage $[5,28]$. Almost all of those studies demonstrated the mechanism by which phenolic compounds prevent hepatotoxicity was due to their antioxidant properties [29]. Phenolic compounds may also contribute directly to antioxidant action, because of their redox properties, which allow them to act as reducing agents, hydrogen donors and singlet oxygen quenchers [29]. Among the identified compounds in BdE, dicaffeoylquinic acids 3, 4 and 5 showed hepatoprotective effects in cultured hepatocytes against $\mathrm{CCl}_{4}$-toxicity. In addition, aromadendrin-4'-O-methyl ether (7) and baccharin (10) had been proved to possess hepatoprotective effect against $\mathrm{D}-\mathrm{GalN} / \mathrm{TNF}-\alpha$-induced cell death in primary cultured mouse hepatocytes [20,30].

Therefore, we found that treatment with BdE markedly inhibits $\mathrm{CCl}_{4^{-}}$and APAP-induced liver damages as evidenced by decreased serum activities of AST, ALT and ALP, which was supported by histopathological examinations. Then, the protective effects of BdE may be due, at least in part, to the increased antioxidant activity and free radical scavenging effects of phenolic compounds and flavonoids present in BdE. Finally, considering that there are differences between experimental animal and human responses to $\mathrm{CCl}_{4}$ - and APAP-induced liver damages, more studies are necessary in order to find out the clinical relevance of the protective effects of BdE.

\section{Experimental}

\subsection{Chemicals}

DPPH free radical (1,1-diphenyl-2-picrylhydrazyl), carbon tetrachloride $\left(\mathrm{CCl}_{4}\right)$, acetaminophen (APAP), silymarin, caffeic, $p$-coumaric and cinnamic acids were purchased from Sigma-Aldrich 
(St. Louis, MO, USA). Artepillin C was purchased from Wako Pure Chemical Industries Co. (Osaka, Japan) and di-O-caffeoylquinic acid derivatives were obtained from PhytoLab (Vestenbergsgreuth, Germany). Aromadendrin-4'-O-methyl ether, drupanin and baccharin were previously isolated and identified as described [19] and kindly donated. Automation reagents for aspartate aminotransferase (AST), alanine aminotransferase (ALT), and alkaline phosphatase (ALP) were purchased from Wiener Lab Group (Rosario, Santa Fe, Argentina). Folin-Ciocalteu reagent, rutin and gallic acid were purchased from Merck (Darmstadt, Germany). All other chemicals were of analytical-reagent grade.

\subsection{Plant Material}

Leaf buds of Baccharis dracunculifolia De Candole were freshly collected at Federal University of Juiz de Fora - UFJF (Juiz de Fora, Minas Gerais State, Brazil) in February 2011. The plant material was previously authenticated by P.L. Viana (Federal University of Minas Gerais), and a voucher specimen (CESJ 47.482) was deposited at the Leopoldo Krieger Herbarium, Institute of Biological Sciences, Federal University of Juiz de Fora, Juiz de Fora, Brazil.

\subsection{Preparation of the Hydroalcoholic Extract of B. dracunculifolia (BdE)}

Leaves were dried and stabilized in a greenhouse of air circulating at $40{ }^{\circ} \mathrm{C}$ for $48 \mathrm{~h}$ and powdered to a fine grade in a blender. Air-dried, powdered leaves $(210 \mathrm{~g})$ were exhaustively extracted with ethanol/ $\mathrm{H}_{2} \mathrm{O}(9: 1 \mathrm{v} / \mathrm{v})$, at room temperature by maceration. The filtered extract was concentrated under vacuum below $45{ }^{\circ} \mathrm{C}$ to furnish $72 \mathrm{~g}$ of the crude hydroalcoholic extract of $B$. dracunculifolia leaves $(\mathrm{BdE})$, which was sealed in a glass bottle and stored at $2{ }^{\circ} \mathrm{C}$ until used.

\subsection{HPLC Analysis of BdE}

HPLC analysis of the BdE was undertaken by using Shimadzu Prominence Liquid Chromatography system (Shimadzu Corporation, Kyoto, Japan) equipped with a CBM-20A controller, four LC-20AT pumps, a SPD-M20A diode-array detector model and Shimadzu LC solution version 1.21 software controller. A Shimadzu Shim-Pack CLC-ODS column $(4.6 \times 250 \mathrm{~mm}$, particle diameter of $5 \mu \mathrm{m}$, pore diameter of $100 \AA$ ) was used. The mobile phase consisted of a buffer solution in pump A (water-formic acid $0.1 \% \mathrm{v} / \mathrm{v}, \mathrm{pH} 2.7$ ) and methanol in pump $\mathrm{B}$. The elution was undertaken using a linear gradient of $20 \%-95 \%$ of $\mathrm{B}$ in $77 \mathrm{~min}$ at a flow-rate of $0.8 \mathrm{~mL} / \mathrm{min}$ and the detection performed at $275 \mathrm{~nm}$. BdE was diluted with $5 \mathrm{~mL}$ of methanol (HPLC grade) in $10 \mathrm{~mL}$ volumetric flasks, sonicated for $40 \mathrm{~min}$, and filled to volume with Milli-Q water. The sample was filtered through a $45 \mu \mathrm{m}$ filter before analysis. All compounds were identified by comparison to their retention times and by co-elution with available authentic chromatographic standards [17], according to the previously reported method [2].

\subsection{DPPH Radical Scavenging Activity}

Free radical-scavenging activity of BdE was estimated using the stable DPPH radical (DPPH) assay [31]. BdE stock solution was prepared in ethanol at a concentration of $1 \mathrm{mg} / \mathrm{mL}$ and diluted to obtain different concentrations $(5-30 \mu \mathrm{g} / \mathrm{mL})$. One milliliter of ethanolic DPPH solution $(100 \mu \mathrm{M})$ was added to $2.5 \mathrm{~mL}$ of ethanolic extract solution at various concentrations. Forty minutes later, the absorbance 
was read at $517 \mathrm{~nm}$, at room temperature, in triplicate, with a Shimadzu UV-VIS 1800 spectrophotometer. The percentage of antioxidant activity (\%AA) was calculated according to the equation:

$$
\% \mathrm{AA}=100-[(\text { sample absorbance/control absorbance }) \times 100]
$$

Thus, the amount of antioxidant required to decrease by $50 \%$ the initial concentration of DPPH was calculated by interpolating the absorbance of the sample against a standard curve of rutin and expressed as $50 \%$ efficient concentration $\left(\mathrm{EC}_{50}\right)$.

\subsection{Total Phenolic Content}

Total phenolic content was determined according to the Folin-Ciocalteu method [32] with some modifications. Two hundred milliliter of BdE solution $(1 \mathrm{mg} / \mathrm{mL})$ was added to $5.0 \mathrm{~mL}$ of Folin-Ciocalteu reagent and mixture was kept at room temperature for $8 \mathrm{~min}$. Four milliliters of 7.5\% aqueous sodium carbonate was added to the mixture. Water was added to adjust the final volume to $15 \mathrm{~mL}$. After $30 \mathrm{~min}$ in the dark, at room temperature, the absorbance was read at $778 \mathrm{~nm}$, in triplicate, with a Shimadzu UV-VIS 1800 spectrophotometer. Total phenolic content was determined by interpolating the absorbance of the sample against a standard curve of gallic acid $(1.0-5.0 \mu \mathrm{g} / \mathrm{mL})$ and expressed as mg of gallic acid equivalent per gram of BdE (mg GAE/g).

\subsection{Total Flavonoid Content}

Total flavonoid content was measured using the aluminum chloride colorimetric method as described by Dewanto, et al. [33] with minor modification. Briefly, $5.0 \mathrm{~mL}$ of BdE ethanolic solution $(10 \mathrm{mg} / \mathrm{mL})$ was added into a centrifuge tube with $2.0 \mathrm{~mL}$ of dichloromethane, $3.0 \mathrm{~mL}$ of distilled water and centrifuged for $3 \mathrm{~min}$. A $2.0 \mathrm{~mL}$ aliquot of the upper layer previously prepared was mixed with $600 \mu \mathrm{L}$ of glacial acetic acid, $10 \mathrm{~mL}$ of pyridine-ethanol solution $(2: 8 \mathrm{v} / \mathrm{v})$ and $2.5 \mathrm{~mL}$ of $8 \%$ ethanolic aluminum chloride were added to a $25 \mathrm{~mL}$ volumetric flask. The total volume of the mixture was adjusted to $25 \mathrm{~mL}$ with distilled water. After $15 \mathrm{~min}$ at room temperature, the absorbance was read at $420 \mathrm{~nm}$, in triplicate, with a Shimadzu UV-VIS 1800 spectrophotometer. Total flavonoid content was expressed as $\mathrm{mg}$ of rutin equivalent per gram of BdE (mg RE/g) from a calibration curve of rutin standard solution $(2.0-30.0 \mu \mathrm{g} / \mathrm{mL})$.

\subsection{Animals}

Male Swiss albino mice (weighing 20-25 g, 5-6 weeks) and male Wistar albino rats (weighting 200-250 g, 8-12 weeks) were used for the experiments. All animals were obtained from the Animal Center of Biology and Reproduction (CBR) of Federal University of Juiz de Fora and held in the experimentation room of Laboratory of Pharmacology of Natural Products, UFJF, Brazil. All animals were grouped and housed in polyacrylic cages $(29 \times 18 \times 16 \mathrm{~cm})$, with beds of sawdust, feed hoppers and water bottle. Moreover, animals were kept at $25 \pm 2{ }^{\circ} \mathrm{C}$, relative humidity $55 \% \pm 5 \%$, with light/dark cycles of 12 h (7:00 to 19:00), received balanced feed Nuvilab Rodents (Nuvital Nutrients, Colombo, Brazil) and water ad libitum. These conditions were maintained for an acclimatization period of 7 days and during the treatment protocol. At the end of the experimental period, animals were sacrificed by withdrawing blood from the inferior vena cava under light diethyl ether anesthesia. 
The serum was obtained by centrifugation and stored at $-80{ }^{\circ} \mathrm{C}$ until analysis and the liver was also removed and stored at $-80{ }^{\circ} \mathrm{C}$ until use. Animals were treated in accordance with the guiding principles established by the Brazilian College of Animal Experimentation and the rules of the Council for International Organizations of Medical Sciences. Experiments were authorized by the Ethical Committee for Animal Care of Federal University of Juiz de Fora (protocols 017/2011 and 034/2012).

\section{9. $\mathrm{CCl}_{4}$-Induced Hepatotoxicity Model}

Mice were randomly divided into seven groups of six animals each, according to a previously reported protocol [34]. In the test groups I-IV, animals were given 10, 25, 50 and $100 \mathrm{mg}$ per kilogram-body weight (bw)/day, orally, using gavage. These doses were based on previous in vivo studies with extracts of $B$. dracunculifolia [6]. Group V (SIL) received silymarin (100 $\mathrm{mg} / \mathrm{kg}$ bw/day) and groups VI $\left(\mathrm{CCl}_{4}\right)$ and VII (normal control) only received vehicle (1\% Tween 80/0.9\% normal saline solution). All administrations were conducted for 7 days. On the seventh day, $2 \mathrm{~h}$ after the last oral administration, a single dose of carbon tetrachloride (intraperitoneally, $5.0 \mathrm{~mL} / \mathrm{kg} \mathrm{bw}$, diluted to $2 \%$ in mineral oil) was applied intraperitoneally to groups I-VI. The vehicle control (group VII) received equivalent amount of mineral oil alone. Animals were sacrificed $16 \mathrm{~h}$ after the $\mathrm{CCl}_{4}$ dose for assessment of liver function and histopathological examinations.

\subsection{APAP-Induced Hepatotoxicity Model}

The experiment was conducted according to method previously described [35] with minor modifications. Rats were randomly divided into five groups of six animals each. Test groups I and II received $\mathrm{BdE}$ at doses of 50 and $100 \mathrm{mg} / \mathrm{kg}$ bw, orally, respectively. Silymarin $(100 \mathrm{mg} / \mathrm{kg} \mathrm{bw})$ was administered to group III (SIL) and groups IV (APAP) and V (normal control) only received vehicle (1\% Tween $80 / 0.9 \%$ normal saline solution). One hour after the treatment (groups I-V), a single dose of acetaminophen (orally, $600 \mathrm{mg} / \mathrm{kg} \mathrm{bw}$, diluted in vehicle) was given to groups I-IV. The vehicle control (group V) only received equivalent amount of saline. Animals were sacrificed $24 \mathrm{~h}$ after the APAP administration for assessment of liver function.

\subsection{Assessment of Liver Function}

Serum biochemical parameters aspartate aminotransferase (AST), alanine aminotransferase (ALT) and alkaline phosphatase (ALP) were measured in an Automation system 3000 plus BT (Wiener lab Group) using commercial kits acquired of Wiener lab. All assays were performed at the Clinical Analysis Laboratory of UFJF, which is certificated by the Brazilian Society of Pathology and Laboratory Medicine.

\subsection{Liver Histopathological Examinations}

The material from total hepatectomy was cleaved along, with long axis of the section from the major hepatic blood vessels and its branches in the right lobe, according to surgical procedure described by Nolan and Leibowitz [36]. After routine histological processing, the staining hematoxylin and eosin (HE) was performed [37]. Sections of $5 \mu \mathrm{m}$ in thickness were analyzed on Zeiss microscope 
(Hallbergmoos, Germany) in increment of $400 \times$, in all its extension to general descriptive histopathological evaluation. The double blind analysis was performed by two different observers with experience and training in histopathology. From this assessment were selected in 400× magnification, representative areas of each sample to capture digital computerized AxioVision ${ }^{\circledR}$ (Zeiss, Berlin, Germany), using digital camera coupled to an optical microscope.

\subsection{Statistical Analysis}

Statistical analysis of the results were performed applying one-way analysis of variance (ANOVA) followed by Tukey post test using GraphPad Prism version 5.04 for Windows software (GraphPad Software, San Diego, CA, USA). All results are expressed as mean \pm standard deviation (S.D.) and values of $p<0.05, p<0.01$, and $p<0.001$ were considered statistically significant.

\section{Conclusions}

Our results demonstrated, for the first time, that the oral treatment with $\mathrm{BdE}$ is effective for prevention of both $\mathrm{CCl}_{4}$ - and APAP-induced liver damage, similarly to Brazilian propolis [12,13]. Then, this study demonstrated that the $B$. dracunculifolia leaves extract has relevant in vivo hepatoprotective properties, supporting its traditional use. However, more detailed in vivo studies are required to establish the safety and clinical relevance of $B$. dracunculifolia leaves extract.

\section{Acknowledgments}

The authors are grateful to CNPq (Proc. 487221/2012-5) and FAPEMIG (Proc. APQ 00171/11) for financial support and PIBIC/CNPq/UFJF, CAPES and CNPq for fellowships. We are also thankful to Jairo K. Bastos (FCFRP-USP) and also to Dra. Andressa Berretta (Apis Flora Comercial LTDA) for HPLC analysis.

\section{Author Contributions}

T.P. Rezende did the biological assays and interpreted the results. B.J.V. Aarestrup and F.M. Aarestrup did the histopathological assays and interpreted the results. J.O.A. Corrêa and O.V. Sousa help to do biological and chemical assays. A.A. Da Silva Filho help to do all assays, interpreted all results, and prepare the manuscript. All authors read and approved the final manuscript.

\section{Conflicts of Interest}

The authors declare no conflict of interest.

\section{References}

1. Sabir, S.M.; Ahmad, S.D.; Hamid, A.; Khan, M.Q.; Athayde, M.L.; Santos, D.B.; Boligon, A.A.; Rocha, J.B.T. Antioxidant and hepatoprotective activity of ethanolic extract of leaves of Solidago microglossa containing polyphenolic compounds. Food Chem. 2012, 131, 741-747. 
2. Guimarães, N.S.; Mello, J.C.; Paiva, J.S.; Bueno, P.C.; Berretta, A.A.; Torquato, R.J.; Nantes, I.L.; Rodrigues, T. Baccharis dracunculifolia, the main source of green propolis, exhibits potent antioxidant activity and prevents oxidative mitochondrial damage. Food Chem. Toxicol. 2012, 50, 1091-1097.

3. León-González, A.J.; Mateos, R.; Ramos, S.; Martín, M.A.; Sarriá, B.; Martín-Cordero, C.; López-Lázaro, M.; Bravo, L.; Goya, L. Chemo-protective activity and characterization of phenolics extracts from Corema album. Food Res. Int. 2012, 49, 728-738.

4. Shankar, N.L.G.; Manavalan, R.; Venkappayya, D.; David Raj, C. Hepatoprotective and antioxidant effects of Commiphora berryi (Arn) Engl bark extract against $\mathrm{CCl}_{4}$-induced oxidative damage in rats. Food Chem. Toxicol. 2008, 46, 3182-3185.

5. Fasalu, R.O.M.; Rupesh, K.M.; Tamizh, M.T.; Mohamed Niyas, K. A review of hepatoprotective natural products. Int. J. Pharm. Sci. Rev. Res. 2011, 8, 80-84.

6. Santos, D.A.; Fukui Mde, J.; Nanayakkara, N.P.D.; Khan, S.I.; Sousa, J.P.; Bastos, J.K.; Andrade, S.F.; da Silva Filho, A.A.; Quintão, N.L. Anti-inflammatory and antinociceptive effects of Baccharis dracunculifolia D.C. (Asteraceae) in different experimental models. J. Ethnopharmacol. 2010, 127, 543-550.

7. Fernandez, E.C.; Sandi, Y.E.; Kokoska, L. Ethnobotanical inventory of medicinal plants used in the Bustillo Province of the Potosi Department, Bolivia. Fitoterapia 2003, 74, 407-416.

8. Sousa, J.P.B.; Jorge, R.F.; Leite, M.F.; Furtado, N.A.J.C.; Bastos, J.K.; da Silva Filho, A.A.; Queiroga, C.L.; Magalhães, P.M.; Soares, A.E.E. Seasonal variation of the $(E)$-nerolidol and other volatile compounds within ten different cultivated populations of Baccharis dracunculifolia D.C. (Asteraceae). J. Essent. Oil Res. 2009, 21, 308-314.

9. Kumazawa, S.; Yoneda, M.; Shibata, I.; Kanaeda, J.; Hamasaka, T.; Nakayama, T. Direct evidence for the plant origin of Brazilian propolis by the observation of honeybee behavior and phytochemical analysis. Chem. Pharm. Bull. 2003, 51, 740-742.

10. Simões, L.M.; Gregório, L.E.; da Silva Filho, A.A.; Souza, M.L.; Azzolini, A.E.; Bastos, J.K.; Lucisano-Valim, Y.M. Effect of Brazilian green propolis on the production of reactive oxygen species by stimulated neutrophils. J. Ethnopharmacol. 2004, 94, 59-65.

11. Jorge, R.; Furtado, N.A.J.C.; Sousa, J.P.B.; da Silva Filho, A.A.; Gregório Junior, L.E.; Martins, C.H.G.; Soares, A.E.E.; Bastos, J.K.; Cunha, W.R.; Silva, M.L.A. Brazilian propolis: Seasonal variation of the prenylated $p$-coumaric acids and antimicrobial activity. Pharm. Biol. 2008, 46, 889-893.

12. Gonzalez, R.; Corcho, I.; Remirez, D.; Rodriguez, S.; Ancheta, O.; Merino, N.; Gonzalez, A.; Pascual, C. Hepatoprotective effects of propolis extract on carbon tetrachloride-induced liver-injury in rats. Phytother. Res. 1995, 9, 114-117.

13. Gonzalez, R.; Remirez, D.; Rodriguez, S.; Gonzalez, A.; Ancheta, O.; Merino, N.; Pascual, C. Hepatoprotective effects of propolis extract on paracetamol-induced liver-damage in mice. Phytother. Res. 1994, 8, 229-232.

14. Da Silva Filho, A.A.; Resende, D.O.; Fukui, M.J.; Santos, F.F.; Pauletti, P.M.; Cunha, W.R.; Silva, M.L.; Gregorio, L.E.; Bastos, J.K.; Nanayakkara, N.P.D. In vitro antileishmanial, antiplasmodial and cytotoxic activities of phenolics and triterpenoids from Baccharis dracunculifolia D.C. (Asteraceae). Fitoterapia 2009, 80, 478-482. 
15. Akanitapichat, P.; Phraibung, K.; Nuchklang, K.; Prompitakkul, S. Antioxidant and hepatoprotective activities of five eggplant varieties. Food Chem. Toxicol. 2010, 48, 3017-3021.

16. Soobrattee, M.A.; Neergheen, V.S.; Luximon-Ramma, A.; Aruoma, O.I.; Bahorun, T. Phenolics as potential antioxidant therapeutic agents: Mechanism and actions. Mutat. Res. 2005, 579, 200-213.

17. Da Silva Filho, A.A.; Sousa, J.P.B.; Soares, S.; Furtado, N.A.J.C.; Andrade e Silva, M.L.; Cunha, W.R.; Gregório, L.E.; Nanayakkara, N.P.D.; Bastos, J.K. Antimicrobial activity of the extract and isolated compounds from Baccharis dracunculifolia D.C. (Asteraceae). Z. Naturforsch. C 2008, 63, 40-46.

18. Missima, F.; da Silva Filho, A.A.; Nunes, G.A.; Bueno, P.C.P.; Sousa, J.P.B.; Bastos, J.K.; Sforcin, J.M. Effect of Baccharis dracunculifolia D.C. (Asteraceae) extracts and its isolated compounds on macrophage activation. J. Pharm. Pharmacol. 2007, 59, 463-468.

19. Sousa, J.P.B.; da Silva Filho, A.A.; Bueno, P.C.; Gregório, L.E.; Furtado, N.A.J.C.; Jorge, R.F.; Bastos, J.K. A validated reverse-phase HPLC analytical method for the quantification of phenolic compounds in Baccharis dracunculifolia. Phytochem. Anal. 2009, 20, 24-32.

20. Banskota, A.H.; Tezuka, Y.; Adnyana, I.K.; Ishii, E.; Midorikawa, K.; Matsushige, K.; Kadota, S. Hepatoprotective and anti-Helicobacter pylori activities of constituents from Brazilian propolis. Phytomedicine 2001, 8, 16-23.

21. Zeashan, H.; Amresh, G.; Singh, S.; Rao, C.V. Hepatoprotective activity of Amaranthus spinosus in experimental animals. Food Chem. Toxicol. 2008, 46, 3417-3421.

22. Recknagel, R.O.; Glende, E.A., Jr.; Dolak, J.A.; Waller, R.L. Mechanisms of carbon tetrachloride toxicity. Pharmacol. Ther. 1989, 43, 139-154.

23. Wu, J.; Danielsson, A.; Zern, M.A. Toxicity of hepatotoxins: New insights into mechanisms and therapy. Expert Opin. Investig. Drugs 1999, 8, 585-607.

24. Gellert, J.; Goldermann, L.; Teschke, R. Effect of $\mathrm{CO}_{2}$-induced hyperventilation on carbon tetrachloride $\left(\mathrm{CCl}_{4}\right)$ levels following acute $\mathrm{CCl}_{4}$ poisoning. Intens. Care Med. 1983, 9, 333-337.

25. Goldermann, L.; Gellert, J.; Teschke, R. Quantitative assessment of carbon tetrachloride levels in human blood by head-space gas chromatography: Application in a case of suicidal carbon tetrachloride intoxication. Intens. Care Med. 1983, 9, 131-135.

26. Jaeschke, H.; Williams, C.D.; McGill, M.R.; Xie, Y.; Ramachandran, A. Models of drug-induced liver injury for evaluation of phytotherapeutics and other natural products. Food Chem. Toxicol. 2013, 55, 279-289.

27. McGill, M.R.; Williams, C.D.; Xie, Y.; Ramachandran, A.; Jaeschke, H. Acetaminophen-induced liver injury in rats and mice: Comparison of protein adducts, mitochondrial dysfunction, and oxidative stress in the mechanism of toxicity. Toxicol. Appl. Pharmacol. 2012, 264, 387-394.

28. Kim, H.P.; Kim, Y.C. Revisiting hepatoprotective natural products from a biological point of view. Nat. Prod. Sci. 2011, 17, 165-174.

29. Cheng, N.; Ren, N.; Gao, H.; Lei, X.; Zheng, J.; Cao, W. Antioxidant and hepatoprotective effects of Schisandra chinensis pollen extract on $\mathrm{CCl}_{4}$-induced acute liver damage in mice. Food Chem. Toxicol. 2013, 55, 234-240. 
30. Basnet, P.; Matsushige, K.; Hase, K.; Kadota, S.; Namba, T. Four di-O-caffeoyl quinic acid derivatives from propolis. Potent hepatoprotective activity in experimental liver injury models. Biol. Pharm. Bull. 1996, 19, 1479-1484.

31. Brand-Williams, W.; Cuvelier, M.E.; Berset, C. Use of a free radical method to evaluate antioxidant activity. Food Sci. Technol. 1995, 28, 25-30.

32. Singleton, V.L.; Rossi, J.A. Colorimetry of total phenolics with phosphomolybdic-phosphotungstic acid reagents. Am. J. Enol. Viticult. 1965, 16, 144-158.

33. Dewanto, V.; Wu, X.; Adom, K.K.; Liu, R.H. Thermal processing enhances the nutritional value of tomatoes by increasing total antioxidant activity. J. Agric. Food Chem. 2002, 50, 3010-3014.

34. Ahmed, M.F.; Rao, A.S.; Ahemad, S.R.; Ibrahim, M. Phytochemical studies and hepatoprotective activity of Melia azedarach Linn, against $\mathrm{CCl}_{4}$ induced hepatotoxicity in rats. J. Pharm. Res. 2012, 5, 2664-2667.

35. Bhadauria, M. Dose-dependent hepatoprotective effect of emodin against acetaminophen-induced acute damage in rats. Exp. Toxicol. Pathol. 2010, 62, 627-635.

36. Nolan, J.P.; Leibowitz, A.I. Endotoxin and the liver. III. Modification of acute carbon tetrachloride injury by polymyxin b - an antiendotoxin. Gastroenterol. 1978, 75, 445-449.

37. Luna, L.G. Manual of Histologic Staining Methods of the Armed Forces Institute of Pathology, 3rd ed.; Mac Graw Hill: New York, NY, USA, 1968; p. 258.

Sample Availability: Not available.

(C) 2014 by the authors; licensee MDPI, Basel, Switzerland. This article is an open access article distributed under the terms and conditions of the Creative Commons Attribution license (http://creativecommons.org/licenses/by/3.0/). 